\title{
Perbedaan Kemampuan Komunikasi Matematis Siswa yang diajar Menggunakan Model Problem Based Learning dan Guided Discovery Learning Berbantuan Geogebra ditinjau dari Gender
}

\author{
Nanda Tia Losi ${ }^{1}$, Mukhtar $^{2}$, Waminton Rajagukguk ${ }^{2}$
}

\begin{abstract}
ABSTRAK
Penelitian ini bertujuan untuk mengetahui: (1) perbedaan kemampuan komunikasi matematis antara siswa yang diajar menggunakan model problem based learning dengan siswa yang diajar menggunakan model guided discovery learning berbantuan GeoGebra; (2) perbedaan kemampuan komunikasi matematis antara siswa laki-laki dan perempuan; (3) interaksi antara model pembelajaran (PBL dan GDL) berbantuan GeoGebra dengan gender terhadap kemampuan komunikasi matematis siswa. Penelitian ini merupakan penelitian quasi eksperimen. Populasi dalam penelitian ini terdiri dari seluruh siswa kelas VIII MTs PAB 1 Helvetia yang berjumlah 190 siswa Tahun Pelajaran 2020/2021, dengan mengambil sampel dua kelas berjumlah 64 siswa. Analisis data dilakukan dengan analisis varians (ANAVA) dua jalur. Hasil penelitian ini menunjukkan bahwa: (1) nilai Fhitung(A) lebih besar daripada nilai Ftabel pada $\alpha=0,05$ yaitu 5,249> 4,001 maka H0 ditolak, artinya terdapat perbedaaan kemampuan komunikasi matematis siswa yang diajar mengggunakan model pembelajaran problem based learning berbantuan GeoGebra dengan siswa yang diajar menggunakan model pembelajaran guided discovery learning berbantuan GeoGebr; (2) nilai Fhitung(B) sebesar 4,750 lebih besar daripada nilai Ftabel pada $\alpha=0,05$ yaitu 4,750> 4,001 maka H0 ditolak, artinya terdapat perbedaaan kemampuan komunikasi matematis antara siswa laki-laki dan perempuan; (3) nilai Fhitung(AB) sebesar 2,277 lebih kecil daripada nilai Ftabel pada $\alpha=0,05$ yaitu 2,277 <4,001, maka H0 diterima yang artinya tidak terdapat interaksi antara model pembelajaran (PBL dan GDL) berbantuan GeoGebra dengan gender terhadap kemampuan komunikasi matematis siswa.
\end{abstract}

Kata Kunci: Komunikasi Matematis, Model Problem Based Learning, Model Guided Discovery Learning, Gender, GeoGebra

\section{PENDAHULUAN}

Dinamika kehidupan masyarakat di era globalisasi abad 21 menuntut sumber daya manusia yang berkualitas dan profesional, serta memiliki kompetensi di pelbagai bidang kehidupan. Pendidikan merupakan usaha sadar dan terencana untuk mewujudkan suasana belajar dan proses pembelajaran agar peserta didik secara aktif mengembangkan potensi dirinya (Sisdiknas, 2003:1). Dengan demikian, pendidikan yang bermutu diharapkan dapat mempersiapkan dan mengembangkan sumber daya manusia yang tangguh dan mampu bersaing secara global.

Kemajuan Ilmu Pengetahuan dan Teknologi yang begitu pesat tidak lepas dari peranan matematika. Pelajaran matematika dapat mengembangkan cara berfikir logis, sistematis dan cermat karena sifat yang dimiliki adalah hierarkis, dinamis, deduktif dan generatif. Boleh dikatakan landasan utama sains dan teknologi adalah matematika. Untuk itu, matematika disekolah perlu difungsikan sebagai wahana untuk menumbuhkembangkan kecerdasan, kemampuan, keterampilan serta untuk membentuk kepribadian siswa. Berdasarkan hasil tes yang diperoleh dari Trends

${ }^{1}$ Corresponding Author: Nanda Tia Losi

Guru Matematika MTs PAB 1 Helvetia, Medan, 20373, Indonesia

E-mail: nandatialosi96@gmail.com

${ }^{2}$ Co-Author: Mukhtar \& Waminton Rajagukguk

Program Studi Pendidikan Matematika Universitas Negeri Medan, Medan, 20221, Indonesia in International Mathematics and Science Study (TIMSS) terlihat bahwa prestasi siswa Indonesia khususnya dalam bidang matematika belum menunjukkan hasil yang memuaskan. Menurut TIMSS pada tahun 2003 Indonesia berada di peringkat ke 35 dari 46 negara dengan nilai 411, pada tahun 2007 Indonesia berada di peringkat ke 36 dari 49 negara dengan nilai 397, pada tahun 2011 Indonesia hanya berada di peringkat ke 38 dari 42 negara yang ikut serta dengan nilai 386 dan pada tahun 2015 Indonesia berada di peringkat ke 44 dari 49 negara peserta dengan nilai rata-rata sebesar 397 (IEA, 2015). Hal ini didukung pula dengan hasil survey World Competitiveness Year Book tahun 2014 dimana Indonesia berada pada ingkat ke 37 dari 60 negara (IMD_WCY, 2014) dan dari hasil PISA 2018, Indonesia berada pada peringkat ke 72 dari 78 negara peserta dengan skor rata-rata 379 , sedangkan skor rata-rata internasional adalah 489 (OECD, 2018). Nilai tersebut cenderung stagnam dalam 10-15 tahun terakhir.

Berdasarkan kondisi tersebut, untuk menghadapi berbagai tantangan perkembangan teknologi informasi yang menuntut sumber daya manusia yang berkualitas, maka dalam pembelajaran matematika yang harus dimiliki dan ditumbuhkembangkan pada siswa salah satunya adalah kemampuan komunikasi matematik siswa. National Council Teacher of Mathematic (NCTM, 2000) menetapkan empat standar kemampuan komunikasi matematis yang mesti dicapai oleh siswa,

Perbedaan Kemampuan Komunikasi Matematis Siswa yang diajar Menggunakan Model Problem Based Learning dan Guided Discovery Learning Berbantuan Geogebra ditinjau dari Gender 
yaitu: 1) organize and consolidate their mathematical thinking through communication (mengorganisasikan dan mengkonsolidasikan pemikiran matematika melalui komunikasi); 2) communicate their mathematical thinking coherently and clearly to peers, teachers, and others (mengkomunikasikan pemikiran matematika dengan logis dan jelas kepada siswa lain, guru dan lainnya); 3) analyze and evaluate the mathematical thinking and strategies of others (menganalisis dan mengevaluasi pemikiran matematika dan strategi lainnya); 4) use the language of mathematics to express mathematical ideas precisely (menggunakan bahasa matematika dengan tepat dalam berbagai ide matematika).

Akan tetapi pada kenyataannya kemampuan komunikasi matematis masih kurang mendapatkan perhatian dari guru. Pada saat melakukan observasi di MTs PAB 1 Helvetia peneliti menemukan bahwa proses pembelajaran masih berpusat pada guru, sehingga proses pembelajaran berjalan dengan pasif. Berdasarkan wawancara yang dilakukan peneliti kepada salah satu guru matematika di MTs PAB 1 Helvetia, guru menganggap pembelajaran konvensional merupakan pembelajaran yang paling efektif digunakan untuk mengejar capaian materi dalam tiap semesternya. Hal ini mengakibatkan guru kerap mengabaikan kemampuan matematis yang harusnya dimiliki siswa melalui pembelajaran di kelas. Berdasarkan obeservasi guru matematika di MTs PAB 1 Helvetia cenderung menggunakan metode ceramah, hal ini menyebabkan siswa lebih pasif dalam belajar dan terbiasa menerima ilmu pengetahuan. Siswa terbiasa untuk mendengarkan penjelasan dari guru, mencatat kemudian mengerjakan latihan soal berpanduan pada contoh soal yang telah dibahas sebelumnya. Dengan demikian peran siswa dalam pembelajaran belum optimal dan sesuai dengan pembelajaran pada kurikulum 2013. Permendikbud 2013 mengatur bahwa proses pembelajaran pada kurikulum 2013 hendaknya terdiri atas lima pengalaman belajar yaitu mengamati, menanya, mengumpulkan informasi, mengasosiasi, dan mengkomunikasikan, yang disingkat dengan 5M. Pengalaman belajar ini dikenal dengan pendekatan saintifik.

Dari fenomena diatas, guru seharusnya mulai menerapkan proses pembelajaran yang membuat siswa terlibat aktif didalamnya, dimana siswa tidak hanya dituntut untuk menyelesaikan masalah yang diberikan, namun siswa juga dituntut untuk mampu mengkomunikasikan pengetahuan yang dimiliki. Upaya yang bisa dilakukan guru salah satunya adalah dengan merombak proses pembelajaran yang biasa diterapkan guru, menjadi proses pembelajaran yang memberikan kesempatan kepada siswa untuk bekerja sama dengan siswa lainnya dalam menyelesaikan tugas-tugas terstruktur. Salah satunya dengan menggunakan model Problem Based Learning (PBL) dan Guided Discovery Learning (GDL).

\section{KAJIAN TEORITIS \\ Komunikasi Matematis}

Romberg dan Chair (Rachmayani, 2014) komunikasi matematis yaitu menghubungkan bendabenda nyata, gambar dan diagram kedalam ide matematika, menjelaskan ide, situasi dan relasi matematik secara lisan ataupun tulisan, menyatakan peristiwa sehari-hari dalam bahasa atau simbol matematika, mendengarkan, berdiskusi, menulis dan membaca tentang matematika, membuat konjektur, menyusun argumen, merumuskan definisi, menjelaskan dan membuat pertanyaan tentang matematika yang telah dipelajari. (Ontario, 2010) Komunikasi matematis merupakan suatu proses penting untuk belajar matematika karena melalui komunikasi peserta didik merefleksikan, mengklarifikasi, mengembangkan ide serta pemahaman dalam argumen yang berhubungan dengan matematika.

Untuk mengukur tingkat kemampuan komunikasi matematis siswa, maka diperlukan indikator yang dapat digunakan secara spesifik untuk mengukur komunikasi matematis siswa. Menurut Elliot \& Kenny (1996) ada beberapa indikator untuk mengukur kemampuan komunikasi matematika, yaitu (1) menyatakan situasi atau masalah matematis atau kehidupan sehari-hari dalam bentuk gambar, diagram, bahasa atau simbol matematik, atau model matematik, (2) menjelaskan suatu ide matematis dengan gambar, ekspresi atau bahasa sendiri secara lisan atau tulisan, (3) membuat suatu cerita berdasarkan gambar, diagram atau model matematika yang diberikan, dan (4) menyusun pertanyaan tentang konten matematik yag diberikan.

Dalam penelitian ini, indikator komunikasi matematis dibatasi pada tiga hal, yaitu: (1) kemampuan menggambar (drawing), yaitu meliputi kemampuan siswa mengungkapkan ide-ide matematika kedalam bentuk gambar, diagram, grafik, tabel dan secara aljabar, (2) kamampuan menulis (written text), yaitu kemampuan memberikan penjelasan dan alasan secara matematika dengan bahasa yang benar dan mudah dipahami, (3) kemampuan ekspresi matematika (mathematical expression), yaitu kemampuan membuat model matematika.

\section{Problem-Based Learning}

Problem Based Learning pertama kali diperkenalkan pada awal tahun 1970 di Universitas Mc Master Fakultas Kedokteran Canada. Mulyatiningsih (2012 : 236) Problem Based Learning merupakan model pembelajaran yang penyampaian materinya dilakukan dengan cara menyajikan suatu permasalahan, mengajukan pertanyaan-pertanyaan, memfasilitasi penyelidikan dan membuka dialog. Problem Based Learning merupakan sebuah model pembelajaran yang menyajikan masalah kontekstual sehingga merangsang siswa untuk belajar. Dalam kelas yang menerapkan pembelajaran berbasis masalah, siswa bekerja dalam tim untuk memecahkan masalah dunia nyata (Kemendikbud, 2013).

Problem Based Learning memiliki karakteristik berpusat pada siswa (Savery, 2006), didesain berdasarkan masalah nyata yang open-ended atau 
ambigu (Hillman, 2003), dan mendorong siswa membangun pemahaman yang kaya mengenai konsep matematika kontekstual melalui serangkaian pertanyaan- pertanyaan yang bersifat konstruktif (Savery \& Duffy, 1995).

Adapun langkah-langkah pembelajaran berbasis masalah menurut Arends (2008) adalah sebagai berikut:

Tabel 1. Sintaks Model Pembelajaran Berbasis Masalah

\begin{tabular}{|c|c|c|}
\hline Fase & Langkah & Kegiatan Guru \\
\hline 1 & Orientasi masalah & $\begin{array}{l}\text { a. Membahas tujuan } \\
\text { pembelajaran. } \\
\text { b. Mendeskripsikan } \\
\text { berbagai kebutuhan } \\
\text { logistik yang } \\
\text { dibutuhkan. } \\
\text { c. Memotivasi peserta } \\
\text { didik untuk terlibat } \\
\text { pada aktivitas } \\
\text { pemecahan masalah } \\
\text { yang dipilih. }\end{array}$ \\
\hline 2 & $\begin{array}{l}\text { Mengorganisasikan } \\
\text { siswa untuk belajar }\end{array}$ & $\begin{array}{ll}\text { a. } & \text { Membantu siswa } \\
\text { mendefinisikan dan } \\
\text { b. } \\
\text { mengorganisasikan } \\
\text { tugas-tugas belajar } \\
\text { yang terkait dengan } \\
\text { permasalahannya. }\end{array}$ \\
\hline 3 & $\begin{array}{l}\text { Membimbing } \\
\text { penyelidikan } \\
\text { individu maupun } \\
\text { kelompok }\end{array}$ & $\begin{array}{l}\text { Mendorong siswa untuk } \\
\text { mengumpulkan informasi } \\
\text { yang sesuai, } \\
\text { melaksanakan eksperimen } \\
\text { untuk mendapatkan } \\
\text { penjelasan dan } \\
\text { pemecahan masalah. }\end{array}$ \\
\hline 4 & $\begin{array}{l}\text { Mengembangkan } \\
\text { dan menyajikn hasil } \\
\text { karya }\end{array}$ & $\begin{array}{l}\text { Membantu siswa dalam } \\
\text { merencakan dan } \\
\text { menyiapkan karya yang } \\
\text { sesuai seperti laporan, } \\
\text { video, dan model-model } \\
\text { serta membantu mereka } \\
\text { untuk } \\
\text { memnyampaikannya } \\
\text { kepada orang lain. }\end{array}$ \\
\hline 5 & $\begin{array}{l}\text { Menganalisis dan } \\
\text { mengevaluasi } \\
\text { proses pemecahan } \\
\text { masalah }\end{array}$ & $\begin{array}{l}\text { Membantu siswa untuk } \\
\text { melakukan refleksi atau } \\
\text { evaluasi terhadap } \\
\text { penyelidikan mereka dan } \\
\text { proses-proses yang } \\
\text { mereka gunakan. }\end{array}$ \\
\hline
\end{tabular}

\section{Guided Discovery Learning}

Discovery Learning atau pembelajaran penemuan diperkenalkan pertama kali oleh Jerome Bruner (1961). Teori ini mendorong peserta didik untuk membangun pengetahuan dan pengalaman masa lalu, menggunakan intuisi, imajinasi dan kreativitas dalam mencari informasi baru untuk menemukan fakta, korelasi dan kebenaran baru. Salah satu bentuk discovery adalah guided discovery (penemuan terbimbing). Penemuan yang dimaksud yaitu siswa menemukan konsep melalui bimbingan dan arahan dari guru karena pada umumnya sebagian besar siswa masih membutuhkan konsep dasar untuk dapat menemukan sesuatu. Guru memberi beberapa petunjuk kepada siswa untuk memperlancar proses berpikirnya dengan memberikan pertanyaan atau ungkapan permasalahan yang membutuhkan pemecahan, menyediakan materi-materi yang sesuai dan menarik, serta meningkatkan kemampuan siswa untuk mengemukakan dan menguji hipotesisnya.

Sucipta, dkk (2018: 2) berpendapat bahwa model pembelajaran penemuan terbimbing (guided discovery) merupakan model pembelajaran yang lebih mengedepankan aktivitas peserta didik dalam menemukan pengetahuannya sendiri, yang dapat diperoleh dari bimbingan teman sebaya dan guru. Pembelajaran penemuan terbimbing (guided discovery learning) merupakan model pembelajaran yang menciptakan situasi belajar yang melibatkan peserta didik belajar secara aktif dan mandiri dalam menemukan suatu konsep atau teori, pemahaman, dan pemecahan masalah. Proses penemuan tersebut membutuhkan guru sebagai fasilitator dan pembimbing. Banyaknya bantuan yang diberikan guru tidak mempengaruhi peserta didik untuk melakukan penemuan sendiri (Ani \& Priansa, 2015:219).

Purwati (2018: 48-50) menyatakan langkah-langkah pembelajaran penemuan terbimbing (guided discovery) akan dijelaskan sebagai berikut:

1. Stimulation (Stimulasi/Pemberian Rangsangan)

Pada tahap ini peserta didik akan dihadapkan pada sesuatu yang menimbulkan kebingungan, kemudian dilanjutkan untuk tidak memberi generalisasi, agar timbul keinginan peserta didik untuk menyelidiki sendiri. Pada tahap ini guru dapat memulai dengan mengajukan pertanyaan, atau meminta peserta didik untuk membaca buku. Langkah stimulasi ini berfungsi untuk membuat peserta didik lebih aktif selama proses pembelajaran.

2. Problem Statement (Pernyataan/Identifikasi Masalah)

Pada tahap ini, guru akan membimbing peserta didik untuk mengidentifikasi dan menganalisis permasalahan/pertanyaan yang diberikan. Selanjutnya peserta didik diminta untuk memberikan prediksi jawaban (hipotesis) terhadap pertanyaan tersebut.

3. Data Collection (Pengumpulan Data)

Tahap ini berfungsi untuk membuktikan benar atau tidaknya hipotesis yang telah peserta didik buat. Kegiatan yang dilakukan guru adalah membimbing peserta didik untuk melakukan kegiatan penemuan dengan mengarahkan peserta didik untuk mengumpulkan berbagai informasi yang dibutuhkan dalam membuktikan kebenaran dari hipotesis yang telah mereka buat.

4. Data Processing (Pengolahan Data)

Pada tahap ini informasi yang telah diperoleh peserta didik akan dianalisis sehingga akan diperoleh suatu kesimpulan atau konsep yang ingin ditemukan. Jika diperoleh suatu perbedaan dari informasi dengan pengolahan data, maka guru perlu membimbing peserta didik untuk melakukan diskusi. 
Vol. 14, No. 1, Juni 2021
5. Verification (Pembuktian)
Pada tahap ini, peserta didik diminta untuk
dianggap sebagai kodrat yang berarti ketentuan biologis atau ketentuan Tuhan oleh masyarakat. melakukan pemeriksaan secara cermat untuk membuktikan benar atau tidaknya hipotesis yang telah ditetapkan. Peran guru pada tahap ini adalah membimbing peserta didik dalam menganalisis data, dan merumuskan kesimpulan/menemukan konsep.

6. Generalization

(Menarik Kesimpulan/Generalisasi)

Tahap generalisasi adalah proses penarikan sebuah kesimpulan dari kegiatan pembelajaran yang telah dilakukan. Sehingga akan diperoleh konsep pembelajaran.

\section{GeoGebra}

GeoGebra merupakan salah satu software yang dapat digunakan dalam menunjang pembelajaran matematika. GeoGebra dikembangakan oleh Markus Hohenwarter dari Universitas Florida Atlantik Amerika tahun 2001. GeoGebra sebagai software matematika dinamis yang dapat digunakan sebagai media pemebelajaran matematika. Awalnya software ini dikembangkan oleh Markus untuk membantunya dalam proses belajar mengajar matematika di Sekolah.

Hohenwarter (Shadaan, 2014) mengemukakan bahwa GeoGebra didesain oleh Markus Hohenwater sebagai open-source perangkat matematika dinamis yang menggabungkan geometri, aljabar, dan kalkulus kedalam suatu paket yang tunggal, terbuka dan gampang dalam penggunaannya. Aplikasi ini dapat dimanfaatkan secara bebas yang dapat diunduh dari www.geogebra.com. GeoGebra melengkapi berbagai program komputer untuk pembelajaran aljabar yang sudah ada, seperti Derive, Maple, MuPad, maupun program komputer untuk pembelajaran geometri, seperti Geometry's Sketchpad atau CABRI.

Menurut Mahmudi dalam Waluyo (2016) pemanfaatan program GeoGebra memberikan beberapa keuntungan, diantaranya adalah sebagai berikut: 1) Lukisan-lukisan geometri yang biasanya dihasilkan dengan cepat dan teliti dibandingkan dengan menggunakan pensil, penggaris, atau jangka; 2) Adanya fasilitas animasi dan gerakan-gerakan manipulasi (dragging) pada program GeoGebra dapat memberikan pengalaman visual yang lebih jelas kepada siswa dalam memahami konsep geometri; 3) Dapat dimanfaatkan sebagai balikan/evaluasi untuk memastikan bahwa lukisan yang telah dibuat benar; 4) Mempermudah guru/siswa untuk menyelidiki atau menunjukkan sifat-sifat yang berlaku pada suatu objek geometri.

\section{Gender}

Secara mendasar, gender berbeda dari jenis kelamin biologis. Jenis kelamin biologis merupakan pemberian, kita dilahirkan sebagai seorang laki-laki atau seorang perempuan. Jalan yang menjadikan kita maskulin atau feminim adalah gabungan blok-blok bangunan biologis dasar dan interprestasi biologis oleh kultur kita. Gender mencakup penampilan, pakaian, sikap, kepribadian, bekerja di dalam dan di luar rumah tangga, seksualitas, tanggung jawab keluarga, dan sebagainya (Mosse, 2007: 2). Gender merupakan konstruksi sosial sering

\section{METODE PENELITIAN}

Penelitian ini merupaan penelitian eksperimen semu (quasi eksperimen). Dalam penelitian quasi eksperimen ini tidak dapat dilakukan pengontrolan terhadap semua variabel luar yang mempengaruhi jalannya penelitian di dalam penelitian ini, pengelompokan kelas eksperimen 1 dan eksperimen 2 dilakukan berdasarkan kelompok yang telah terbentuk sebelumnya atau kelompok yang telah ada. Perlakuan dalam penelitian ini adalah pembelajaran matematika dengan model pembelajaran Problem Based Learning berbantuan GeoGebra dan Guided Discovery Learning berbantuan GeoGebra, sedangkan variabel yang diamati adalah kemampuan komunikasi matematis siswa.

Penelitian ini dilakukan di MTs Swasta PAB 1 Helvetia kelas VIII Jl. Veteran Psr. IV Helvetia Kecamatan Labuhan Deli pada semester genap Tahun Pelajaran 2020/2021. Populasi dalam penelitian ini adalah seluruh siswa MTs Swasta PAB 1 Helvetia yang berada di Kecamatan Labuhan Deli. Pemilihan siswa MTs sebagai populasi penelitian ini didasarkan pada pertimbangan bahwa banyak topik materi matematika yang sangat menarik apabila diajarkan dengan menggunakan Model pembelajaran Problem Based Learning berbantuan GeoGebra dan Guided Discovery Learning berbantuan GeoGebra. Di samping itu, dipilihnya siswa MTs karena diasumsikan sudah matang untuk menerima perubahan dalam menerapkan model pembelajaran yang dilakukan guru.

Proses pengambilan sampel merujuk pada ukuran populasi. Teknik pengambilan sampel kelompok dilakukan secara acak (random sampling). Tahap pemilihan secara acak dimungkinkan karena berdasarkan informasi dari kepala sekolah dan guru, pendistribusian siswa pada tiap kelas merata secara heterogen. Sehingga pemilihan sampel dalam penelitian ini adalah dengan penomoran tiap kelas pada kertas lalu dilakukan undian. Kelas VIII di MTs Swasta PAB 1 Helvetia terdiri dari 4 kelas. Sampel yang terpilih adalah kelas VIII-C sebagai kelas eksperimen-1 dan kelas VIII-D sebagai kelas eksperimen-2.

Penelitian ini melibatkan dua kelas sampel yang dipilih sebagai representasi dari populasi dan dijadikan sebagai kelas eksperimen. Kedua kelas eksperimen tersebut diberikan perlakuan dengan menerapkan pembelajaran yang berbeda yaitu problem based learning dan guided discovery learning berbantuan GeoGebra. Kelas ekperiemen-1 diberi perlakuan berupa pembelajaran problem based learning berbantuan GeoGebra dan kelas eksperimen2 diberi perlakuan berupa pembelajaran guided discovery learning berbantuan GeoGebra. Setelah diberi perlakuan pada kedua kelas ekperimen selanjutnya diberikan tes akhir untuk melihat 
perbedaan kemampuan komunikasi matematis pada kedua kelas.

Tes kemampuan komunikasi matematis dalam penelitian ini berbentuk uraian sebanayak 6 soal. Setelah melakukan uji coba, pengolahan data diawali dengan menguji persyaratan uji statistik yang diperlukan sebagai dasar dalam pengujian hipotesis, antara lain adalah uji normalitas data dan uji homogenitas varians. Selanjutnya dilakukan uji Anava dua jalur yang disesuaikan dengan rumusan masalah yaitu untuk melihat signifikansi perbedaan kemampuan komunikasi matematis siswa dan interaksi pembelajaran dengan gender. Analisis varians bertujuan untuk membandingkan rata-rata dari beberapa populasi atau jika dikaitkan dengan suatu rancangan eksperimen maka analisis varians bertujuan untuk menguji signifikansi perbedaan efek dari perlakuan-perlakuan terhadap variabel terikat (Syahputra, 2016: 139). Analisis varians juga merupakan salah satu univariat yang dapat digunakan untuk mengetahui pengaruh dan interaksi dua faktor dengan satu variabel dependen yang bertipe atau rasio dan beberapa variabel independen yang bertipe nominal atau ordinal. ANAVA dua jalur juga diguanakan untuk mengetahui adanya interaksi (Kadir, 2015: 346).

Dalam penelitian ini ada tiga hipotesis yang akan diuji, yang akan diuraikan sebagai berikut: (1) Terdapat perbedaan kemampuan komunikasi matematis antara siswa yang diajar menggunakan model Problem Based Learning berbantuan GeoGebra dengan siswa yang diajar menggunakan model Guided Discovery Learning berbantuan GeoGebra, (2)Terdapat perbedaan kemampuan komunikasi matematis antara siswa laki-laki dan perempuan, dan (3) Terdapat interaksi antara model pembelajaran (PBL dan GDL) berbantuan GeoGebra dengan gender terhadap kemampuan komunikasi matematis siswa. Secara lengkap prosedur penelitian yang peneliti laksanakan dalam penelitian ini, dapat dilihat pada Gambar dibawah ini.

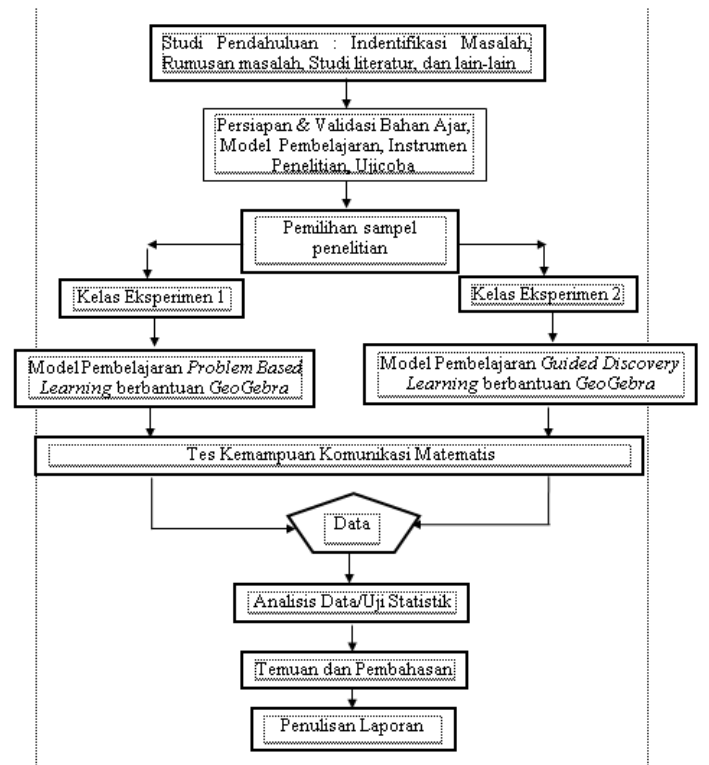

Gambar 1. Alur Penelitian

\section{HASIL PENELITIAN}

Analisis data tes kemampuan komunikasi matematis siswa ditujukan untuk menguji hipotesis, yaitu: (1) Terdapat perbedaan kemampuan komunikasi matematis siswa yang memperoleh model pembelajaran PBL berbantuan GeoGebra dengan siswa yang memperoleh model pembelajaran GDL berbantuan GeoGebra, (2) Terdapat perbedaan kemampuan komunikasi matematis antara siswa lakilaki dan perempuan, (3) Terdapat interaksi antara model pembelajaran (PBL dan GDL) berbantuan GeoGebra dengan gender terhadap kemampuan komunikasi matematis siswa.

Pengujian hipotesis dilakukan dengan menggunakan adalah Anava dua jalur. Sebelumnya telah dilakukan uji prasyarat yaitu uji homogenitas dan uji normalitas data tes dan kedua kelas eksperimen telah memenuhi syarat berdistribusi normal dan kedua kelas memilki varians yang sama. Pengujian hipotesis diuraikan pada tabel 2 berikut ini.

Tebel 2. Data Hasil Uji Hipotesis

\begin{tabular}{lccccc}
\hline \multicolumn{1}{c}{ Sumber Varians } & $\mathrm{JK}$ & $\mathrm{db}$ & $\mathrm{RJK}$ & $\mathrm{F}_{\text {hitung }}$ & $\begin{array}{c}\mathrm{F}_{\text {tabel }} \\
(\alpha=0,05)\end{array}$ \\
\hline Pembelajaran (A) & 456,000 & 1 & 456,000 & 5,249 & 4,001 \\
\hline Gender (B) & 412,598 & 1 & 412,598 & 4,750 & 4,001 \\
\hline $\begin{array}{l}\text { Pembelajaran*Gender } \\
(\mathrm{AB})\end{array}$ & 197,754 & 1 & 197,754 & 2,277 & 4,001 \\
\hline Dalam & 5211,589 & 60 & 86,859 & & \\
\hline Total & 6227,941 & 63 & & & \\
\hline
\end{tabular}

\section{Pengujian Hipotesis 1}

Hipotesis pertama yang akan diuji adalah terdapat perbedaan kemampuan komunikasi matematis siswa yang memperoleh pembelajaran PBL dengan siswa yang memperoleh pembelajaran GDL. Berdasarkan Tabel 2 untuk perhitungan pada model pembelajaran (A) diperoleh nilai $F_{\text {hitung(A) }}$ sebesar 5,249. Karena $\mathrm{F}_{\text {hitung(A) }}$ lebih besar daripada nilai $\mathrm{F}_{\text {tabel }}$ pada $\alpha=0,05$ yaitu 5,249 > 4,001 maka $\mathrm{H}_{0}$ ditolak. Artinya terdapat perbedaan yang signifikan antara kemampuan komunikasi matematis antara siswa yang memperoleh pembelajaran problem based learniing berbantuan GeoGebra dengan siswa yang memperoleh pembelajaran guided discovery learniing berbantuan GeoGebra.

\section{Pengujian Hipotesis 2}

Hipotesis kedua yang akan diuji adalah terdapat perbedaan kemampuan komunikasi matematis siswa laki-laki dan perempuan. Berdasarkan Tabel 2 untuk perhitungan pada gender (B) diperoleh nilai Fhitung(B) sebesar 4,750. Karena Fhitung(B) lebih besar daripada nilai Ftabel pada $\alpha=0,05$ yaitu 4,750 > 4,001 maka H0 ditolak. Artinya terdapat perbedaan yang signifikan antara komunikasi matematis antara siswa laki-laki dan perempuan.

Pengujian Hipotesis 3

Hipotesis ketiga yang akan diuji adalah terdapat interaksi antara model pembelajaran (problem based

Perbedaan Kemampuan Komunikasi Matematis Siswa yang diajar Menggunakan Model Problem Based Learning dan Guided Discovery Learning Berbantuan Geogebra ditinjau dari Gender 
Vol. 14, No. 1, Juni 2021

learning dan guided discovery learning) dengan gender (laki-laki dan perempuan) terhadap kemampuan komunikasi matematis siswa. Berdasarkan Tabel 2, untuk perhitungan interaksi model pembelajaran dan gender diperoleh bahwa nilai Fhitung(AB) sebesar 2,277. Karena Fhitung(AB) lebih kecil daripada nilai Ftabel pada $\alpha=0,05$ yaitu $2,277<4,001$, maka H0 diterima. Artinya tidak terdapat interaksi antara model pembelajaran berbantuan GeoGebra (problem based learning dan guided discovery learning) dengan gender terhadap kemampuan komunikasi matematis antara siswa. Ini menunjukkan bahwa tidak terdapat pengaruh secara bersama-sama yang diberikan model pembelajaran dan gender terhadap perbedaan kemampuan komunikasi matematis siswa. Secara grafik, interaksi tersebut dapat dilihat pada Gambar 1.

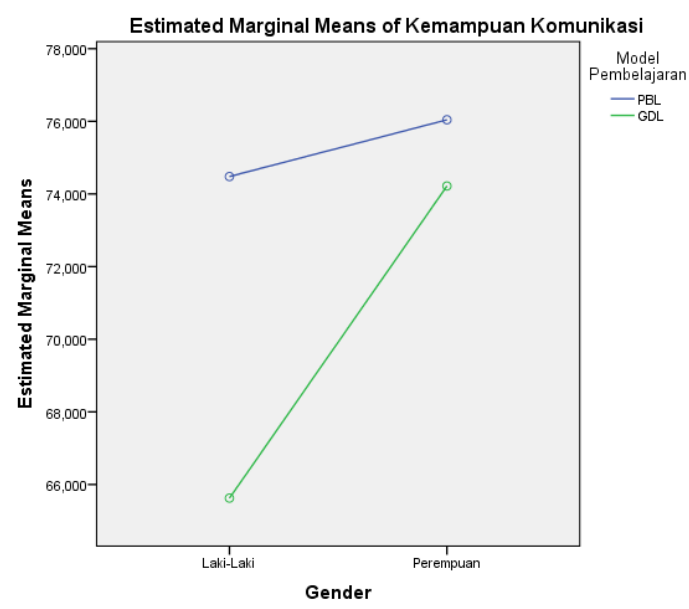

Gambar 2. Grafik Interaksi antara Pembelajaran dengan Gender terhadap Kemampuan Komunikasi Matematis Siswa

Dari Gambar 2 di atas memperlihatkan bahwa garis pembelajaran PBL tidak berpotongan dengan garis pembelajaran GDL. Dari rata-rata kemampuan komunikasi matematis siswa yang menggunakan model pembelajaran PBL terlihat bahwa kemampuan komunikasi matematis siswa perempuan lebih tinggi daripada siswa laki-laki. Begitupula dengan kemampuan komunikasi matematis siswa yang menggunakan model pembelajaran GDL, kemampuan komunikasi matematis siswa perempuan lebih tinggi dari pada siswa laki-laki. Jika dilihat dari selisih rerata nilai tes kedua pembelajaran, untuk rerata selisih nilai siswa laki-laki adalah 8,854 sedangkan selisih nilai siswa perempuan adalah 1,824. Hal ini berarti model pembelajaran dapat mempengaruhi kemampuan komunikasi matematis siswa pada tiap gender. Hal ini berarti bahwa tidak terdapat pengaruh secara bersama-sama yang disumbangkan oleh model pembelajaran dan gender terhadap kemampuan komunikasi maematis siswa. sehingga dapat disimpulkan bahwa tidak terdapat interaksi antara pembelajaran dan gender terhadap kemampuan komunikasi matematis siswa.

\section{PEMBAHASAN}

Pada bagian ini akan diuraikan pembahasan penelitian sesuai dengan deskripsi hasil penelitian dan analisis data penelitian sebelumnya. Pembahasan hasil penelitian akan diuraikan berdasarkan beberapa faktor yang terkait dalam penelitian ini, yakni faktor model pembelajaran, kemampuan komunikasi matematis siswa, interaksi antara model pembelajaran berbantuan GeoGebra (problem based learning dan guided discovery learning) dengan gender (laki-laki dan perempuan) terhadap kemampuan komunikasi matematis siswa. Secara lengkap uraian tersebut dideskripsikan sebagai berikut.

\section{Faktor Pembelajaran}

Hasil penelitian menunjukkan bahwa kemampuan komunikasi matematis siswa yang memperoleh pembelajaran problem based learning berbantuan GeoGebra lebih tinggi dibandingkan siswa yang memperoleh pembelajaran guided discover learning berbantuan GeoGebra. Pada pembelajaran problem based learning, siswa terlihat lebih aktif dalam menyelesaikan permasalahan yang diberikan oleh guru. Masalah yang diberikan adalah masalah yang kontekstual yang berkaitan dengan kehidupan seharihari, dimana siswa menyelesaikan masalah dan menemukan konsep matematika terkait materi yang sedang dipelajari.

Pembentukan kelompok diskusi siswa berdasarkan yang heterogen membuat siswa dapat saling berbagi informasi dan menyelesaikan masalah dengan baik. Peran guru sebagai mediator dalam pembelajaran dan pertanyaan-pertanyaan dalam LKPD sebagai stimulus membantu siswa untuk menyelesaikan masalah dengan baik.

Diawal pembelajaran pertemuan pertama di kelas GDL siswa butuh waktu lama untuk mengikuti tahapan matematis yang terdapat pada LKPD. Hal ini dikarenakan siswa belum terbiasa menyelesaikan masalah dengan tahapan matematis yang terdapat pada LKPD, namun siswa terus mengalami progress yang semakin baik dalam proses berpikirnya secara individual dan kelompok. Melalui tahapan-tahapan pada LKPD siswa memahami masalah matematis dengan mencari keterkaitan konsep dari masalah yang disajikan. Pada awalnya sulit bagi siswa sebab siswa belum terbiasa mengaitkan konsep matematika.

Pada pembelajaran problem based learning, siswa terlibat aktif dalam memperoleh pengetahuan baru dengan menggabungkan pengalaman/pengetahuan yang telah dimiliki sebelumnya dengan informasi baru yang diterima dalam pembelajaran. Pembelajaran diawali dengan pemberian masalah autentik pada LKPD, selanjutnya siswa diminta untuk bekerja sama dalam kelompok dan dibimbing secukupnya oleh guru. Siswa dituntut untuk mampu mendefinisikan dan mengorganisasikan tugas-tugas belajar yang terkait dengan permasalahannya, mengumpulkan informasi yang sesuai, melaksanakan eksperimen untuk mendapatkan pemecahan masalah, serta menyiapkan karya yang nantinya akan disajikan kepada kelompok lain. Dalam hal ini, siswa akan mendapatkan 
pengetahuan yang akan melekat lama dalam dirinya karena pengetahuan baru tersebut ditemukan bersamasama dan ini akan membantu siswa untuk menyelesaikan masalah yang terkait.

Siswa masing-masing bertanggung jawab atas aktivitas belajar anggota kelompok-kelompoknya sehingga seluruh anggota kelompok dapat menguasai materi pelajaran dengan baik dan menyelesaikan masalah yang diberikan. Sedangkan dalam pembelajaran guided discovery learning, siswa juga terlibat aktif dalam memperoleh pengetahuan baru dengan menggabungkan pengalaman/pengetahuan yang telah dimiliki sebelumnya dengan informasi baru yang diterima dalam pembelajaran. Pembelajaran diawali dengan pengamatan, yaitu siswa diberikan kesempatan untuk mengamati dan mengidentifikasi masalah yang ada pada LKPD dengan cara bekerja sama dalam kelompok dan memperoleh bimbingan dari guru yang berperan sebagai fasilitator. Siswa dituntut untuk dapat memahami masalah, mengidentifikasi masalah, mengumpulkan data, mengolah data, menguji hasil, dan kemudian menyimpulkannya. Dalam mengerjakan masalah pada LKPD, siswa akan menemukan pengetahuan/konsep dari materi yang sedang dipelajari, yang selanjutnya akan digunakan untuk memecahkan masalah yang berkenaan dengan materi yang disediakan pada LKPD tersebut.

\section{Kemampuan Komunikasi Matematis}

Berdasarkan hasil analisis data, kedua kelas sampel yaitu kelas eksperimen-1 dan kelas eksperimen-2 memiliki varians yang sama dan kedua kelompok data berdistribusi normal, sehingga dapat dilakukan pengujian hipotesis dengan uji Anava dua jalur. Dari hasil pengujuan Anava dua jalur diketahui bahwa terdapat perbedaan yang signifikan antara siswa yang memperoleh pembelajaran problem based learning dan siswa yang memperoleh pembelajaran guided discovery learning. Jika ditinjau dari rata-rata nilai, kelas ekperimen-1 yang memperoleh pembelajaran problem based learning memiliki rata-rata nilai sebesar 75,260 sedangkan kelas eksperimen-2 yang memperoleh pembelajaran guided discovery learning memiliki nilai rata-rata sebesar 69,922. Hal ini berarti kemampuan komunikasi matematis siswa yang memperoleh pembelajaran problem based learning berbantuan GeoGebra lebih tinggi dibandingkan siswa yang memperoleh pembelajaran guided discovery learning berbantuan GeoGebra.

Interaksi antara Model Pembelajaran dengan Gender terhadap Komunikasi Matematis Siswa

Interaksi adalah kerjasama dua variabel bebas atau juga lebih dalam memberikan pengaruh kepada variabel terikat. Dalam penelitian ini interaksi yang diteliti adalah kerjasama antara model pembelajaran (problem based learning dan guided discovery learning berbantuan GeoGebra) dengan gender terhadap kemampuan komunikasi matematis siswa. Pada penelitian ini faktor pembelajaran dan gender diuji untuk melihat pengaruhnya terhadap kemampuan komunikasi matematis. Dari hasil analisis deskriptif, rata-rata nilai kemampuan komunikasi matematis siswa laki-laki di kelas eksperimen-1 sebesar 74,48 dan kemampuan komunikasi matematis siswa perempuan adalah 76,04. Sedangkan rata-rata nilai kemampuan komunikasi matematis siswa laki-laki di kelas eksperimen-2 adalah 65,63 dan untuk kemampuan komunikasi siswa perempuan nya sebesar 74,22. Hal ini menunjukkan kemampuan komunikasi matematis siswa dikelas eksperimen-1 yang memperoleh pembelajaran problem based learning lebih tingggi dibandingkan kelas eksperimen-2 yang memperoleh pembelajaran guided discovery learning.

Berdasarkan analisis statistik dengan menggunakan ANAVA dua jalur, menunjukkan nilai signifikansi sebesar 0,137 dimana nilai signifikansi lebih besar dari 0,05. Sehingga, H0 diterima, artinya, secara signifikan tidak terdapat interaksi antara model pembelajaran dengan gender terhadap kemampuan komunikasi matematis siswa. Secara teoritis, interaksi terjadi diakibatkan oleh pembelajaran yang digunakan oleh guru selama proses belajar mengajar yang mampu untuk mengembangkan kemampuan siswa dalam matematika bukan karena gender siswa yang berbedabeda. Penerimaan ini terjadi bisa saja diakibatkan oleh pemilihan sampel yang kurang tepat, waktu penelitian yang relatif singkat dan ada beberapa siswa baik lakilaki maupun perempuan yang tidak hadir ke sekolah sehingga berakibat pada perbedaan peningkatan kemampuan komunikasi matematis di dengan menggunakan model pembelajaran problem based learning dan guided discovery learning berbantuan GeoGebra.

\section{KESIMPULAN}

Berdasarkan hasil analisis data penelitian tentang kemampuan komunikasi matematis siswa yang diajar menggunakan model pembelajaran problem based learning dan guided discovery learning berbantuan Geogebra, maka diperoleh beberapa kesimpulan sebagai berikut :

1. Kemampuan komunikasi matematis siswa yang diajarkan dengan menggunakan model pembelajaran problem based learning berbantuan aplikasi GeoGebra lebih tinggi dibandingkan dengan siswa yang diajarkan menggunakan model guided discovery learning berbantuan aplikasi GeoGebra.

2. Komunikasi matematis siswa perempuan lebih tinggi dibandingkan siswa laki-laki.

3. Tidak ada interaksi antara model pembelajaran (PBL dan GDL) berbantuan GeoGebra dengan gender terhadap kemampuan komunikasi matematis siswa.

\section{UCAPAN TERIMA KASIH}

Pada kesempatan kali ini penulis juga mengucapkan banyak terimakasih kepada seluruh pihak yang telah memberi dukungan dan motivasi serta masukan yang membangun, baik sejak memulai penelitian hingga selesai. Ucapan terimakasih dan penghargaan khususnya penulis sampaikan kepada orang tua dan keluarga yang selalu memberi dukungan penuh dan 
memotivasi penulis. Bapak Prof. Dr. Bornok Sinaga,

M.Pd selaku Direktur Program Pascasarjana Universitas Negeri Medan, Bapak Dr. Mulyono, M.Si selaku Ketua Prodi Pendidikan Matematika dan Bapak Mangaratua M. Simanjorang, Ph.D selaku Sekertaris Prodi Pendidikan Matematika Program Pascasarjana Universitas Negeri Medan, Bapak Satria Wiraprana, S.Pd selaku Kepala MTs PAB 1 Helvetia dan Ibu Yolanda Rizkia Putri, S. Pd beserta seluruh Bapak/Ibu Guru dan pegawai serta para siswa di MTs PAB 1 Helvetia yang telah memberikan kesempatan untuk melakukan penelitian disekolah tersebut.

\section{REFERENSI}

Departemen Pendidikan Nasional. (2003). UndangUndang No. 20 tahun 2003 Tentang Sistem Pendidikan Nasional. Jakarta

Bruner, J.S. (1961). "The Act of Discovery". Romey, W.D. (1968). Inquiry Techniques For Teaching Science. New Jersey : Prentice Hall, INC., Englewood Cliffts.

Depdiknas. (2003). Undang-undang RI No.20 tahun 2003 Tentang Sistem Pendidikan Nasional.

Hillman, W. (2003). Learning How to Learn : Problem Based Learning.. Australian Journal of Teacher Education, 28(2). http://dx.doi.org/10.14221/ajte.2003v28n2.1

IEA's Trends in Internasional Mathematics and Science Study. (2016). Math Student Achivement Info graphic Grade 4. TIMSS 2015. Diakses dari http://timss2015.org/download-center

Kadir. (2015). Statistika Terapan : Konsep, Contoh, dan Analisa Data dengan Program SPSS/Lisrel dalam Peneltian. Jakarta : PT Rajagrafindo Persada.

Kemendikbud. (2014). Peraturan Menteri Pendidikan dan Kebudayaan, Nomor 58, Tahun 2014, tentang Kurikulum 2013 Sekolah Menengah Pertama (SMP) / Madrasah Tsanawiyah (MTs)

Kemendikbus. (2013). Permendikbud Nomor 65 Tahun 2013 Tentang Standar Proses. Jakarta: Kemendikbud.

Kemendikbus. (2013). Permendikbud Nomor $81 a$ Tahun 201, Implementasi Kurikulum, Lmpiran IV. Jakarta: Kemendikbud.

Mulyatiningsih, Endang. (2012). Metode Penelitian Terapan Bidang Pendidikan. Bandung: Alfabeta.

NCTM. (2000). Principles and Standards for School Mathematics. United States of America : The National Council of Teachers of Mathematics, Inc.

OECD. (2018). PISA 2015 Result in Focus .Kanada: OECD. https://www.oecd.org (diakses pada 08 Januari 2021)

Savery , John.R, Duffy, Thomas.M. (1995). Problem Based Learning : An Intructional Model and Its Constructivist Framework. Bloomingtoon : Indiana University.[online].

Syahputra, Edi. (2016). Statistika Terapan. Medan: UNIMED PRESS. 